\title{
KEMISKINAN DI PERDESAAN DALAM TINJAUAN MORFOLOGI SOSIAL (Studi Kasus Kemiskinan di Desa Sumber Salak Kecamatan Curahdami Kabupaten Bondowoso Jawa Timur)
}

\author{
Dhanny S. Sutopo \\ Fakultas Ilmu Sosial Dan Ilmu Politik Universitas Brawijaya \\ Email: sutopo_dhanny@ub.ac.id
}

\begin{abstract}
ABSTRAK. Penelitian ini secara khusus mempelajari tantang hubungan kondisi ekologis suatu daerah perdesaan dengan kondisi warga masyarakatnya dengan meletakkannya dalam bingkai kemiskinan yang melanda desa ini sejak dulu hingga sekarang ini. Dengan mengambil kasus di Desa Sumber Salak Kecamatan Curahdami Kabupaten Bondowoso, penelitian ini diharapkan dapat berkontribusi terhadap studi-studi kemiskinan di wilayah Jawa Timur. Mengingat bahwa pekerjaan besar bangsa Indonesia ini adalah masalah pengentasan kemiskinan, maka pada penelitian ini mencoba memberikan gambaran mendasar bagaimana beberapa desa masih dalam kubangan kemiskinan hingga penyebabnya dapat dipelajari secara mendalam dan holistik. Untuk itu sentuhan metode penelitian yang digunakan adalah metode etnografi hal ini agar karakter kuat untuk mendapatkan apa yang disebut Clifford Geertz dengan thick description. Hasil dari penelitian ini menunjukkan bahwa kondisi kemiskinan demikian ini disebabkan karena beberapa hal mendasar, yaitu: (1) mayoritas warga sebagai petani memiliki derajat ketergantungan yang tinggi terhadap tanah yang menjadi sumber penghidupan mereka di bidang pertanian, (2) dalam hal produksi ruang pertanian yang sangat bergantung pada iklim, (3) tingkat hasil produksinya tidak cukup memberikan keuntungan bagi pemenuhan kebutuhan hidup mayoritas warga sebagai buruh petani karena ketiadaan kepemilikan lahan pertanian - karena lahan secara terbatas hanya dimiliki oleh segelintir warga, dan (4) ketergantungan mayoritas warga terhadap pemilik lahan menjadikan struktur sosial yang erat kaitannya dengan lahan, sehingga tercipta kemiskinan sebagai bentuk morfologi sosial.
\end{abstract}

Kata kunci: kemiskinan, petani, buruh, morfologi sosial

\section{POVERTY IN RURAL THE SOCIAL MORPHOLOGY}

(A Case Study Poverty In The Sumber Salak Village In Curahdami District Bondowoso East Java)

\begin{abstract}
This study specifically studies of relations ecological condition an area of rural areas by the state of residents people by placing it in a frame poverty in village this a long time ago until now. By taking the case in the village of Sumber Salak in Curahdami Bondowoso district, research is expected to contribute to studies poverty in in east java. Given that a great job indonesian it is a matter of poverty reduction, so on this study tries to provide a fundamental how some villages are still in puddle poverty to the cause can be learned have an in-depth and holistic. For that touch research methodology used is the method ethnography this matter in a strong character to get what called clifford geertz with thick description. The result of the research indicated that these conditions for some respects, namely: (1) as farmers degrees high dependency on land be a source of their livelihood, (2) relies heavily on climate , (3) produce not enough benefit (4) dependence the majority of citizens against owners, so as to create poverty as a form of social morphology.
\end{abstract}

Key words: poverty, farmers, laborers, morphology social

\section{PENDAHULUAN}

Gagasan penelitian ini berangkat dari kenyataan empiris tentang desa yang masih berselimut dengan persoalan kesejahteraan. Sehingga konsentrasi studi ini padakemiskinan yang terjadi di desa serta hubungan antara kemiskinan tersebut dengan struktur sosial yang secara spesifik berangkat dari permasalahan morfologi sosialnya. Kemiskinan yang terjadi di Desa Sumber Salak, sangat terkait dengan pembacaan morfologi sosial tersebut. Untuk lebih menguatkan kembali bagaimana pembacaan kemiskinan dalam tinjauan morfologi sosial, di dalamnya terdapat kompleksitas yang dapat diterjemahkan sebagai bentuk ruang fisik dan ruang sosial. Ruang fisik terkait dengan lingkungan fisik (misalnya lahan, luasan lahan dan kondisi lahan) dan iklim wilayah. Sedangkan ruang sosial terkait dengan demografi masyarakat (misalnya pekerjaan dan pendapatan). Antara ruang fisik dan ruang sosial ini, selanjutnya dikonstruksikan secara sosial dan juga secara adaptif seiring dengan waktu yang berjalan menciptakan apa yang disebut dengan struktur sosial. Struktur sosial inilah yang menguatkan bagaimana basis kemiskinan dapat terpelihara sedemikian rupa sejak dulu dan berjalan terus hingga kini. Kesemuanya itu bergerak dalam ruang-ruang disebutkan tadi yang pada akhirnya memformulasikan sebuah struktur sosial masyarakat yang berbentuk wajah kemiskinan di Desa Sumber Salak.

Desa Sumber Salak merupakan bagian dari Kecamatan Curahdami Kabupaten Bondowoso. Desa ini merupakan desa paling muda yang secara definitif baru berdiri tahun 2007 sebelumnya merupakan bagian dari Desa Pakuwesi. Secara kesejarahan sebelumnya di tahun 2005, Desa Pakuwesi pernah mengalami gejolak sosial yang berbau politik lokal, yaitu maraknya protes yang ditujukan pada perangkat Desa Pakuwesi yang dilakukan oleh warga dari beberapa dusun di bagian atas dari desa 
ini, yaitu salah satunya Dusun Sumber Salak. Hal ini dipicu oleh ketidakpuasan warga dari beberapa dusun tersebut yang beranggapan bahwa pembangunan di Desa pakuwesi mengalami kemandekan dan kesejahteraan warga tidak mengalami peningkatan yang berarti. Karena itu warga dari beberapa dusun, yaitu Sumber Salak, Gunung Piring, Taman Raja, dan Duk Dabah melakukan protes yang kemudian berdampak pada tuntutan mereka untuk untuk melakukan pemekaran. Pada akhirnya tahun 2005 Desa Pakuwesi mengalami pemekaran dari keempat dusun bergabung menjadi satu desa otonom hingga sekarang kita mengenalnya sebagai Desa Sumber Salak. Pada tahun 2005 dibentuk pemerintahan desa sementara sebelum disahkan pada tahun 2007, ketika itu desa sudah memiliki perangkat yang definitif. Semenjak tahun 2007 itulah merupakan kelahiran Desa Sumber Salak yang berlangsung kepemerintahan desanya hingga sekarang.

Dari gambaran latar belakang di atas, maka permasalahan penelitian ini dapat dirumuskan sebagai berikut: "Bagaimana kondisi kemiskinan di perdesaan yang diakibatkan oleh kondisi morfologi sosial di Desa Sumber Salak Kecamatan Curahdami Kabupaten Bondowoso Jawa Timur?"

Dari perumusan masalah tersebut pada dasarnya penelitian ini dibangun dari sifat keterhubungan antara konsep kemiskinan, konsep masyarakat perdesaan dan konsep morfologi sosial. Sifat keterhubungan antar konsep ini menghasilkan penjelasan yang secara holistik dapat menjawab apa yang menjadi rumusan pertanyaan penelitian ini.

Tujuan penelitian ini difokuskan untuk menjawab rumusan pertanyaan yang telah dikemukakan, yaitu untuk menganalisis dan memahami kondisi kemiskinan di perdesaan yang diakibatkan oleh kondisi morfologi sosial di Desa Sumber Salak Kecamatan Curahdami Kabupaten Bondowoso Jawa Timur.

\section{METODE}

Penelitian inimenggunakan pendekatan kualitatif yang dimulai dengan asumsi dan penggunaan kerangka penafsiran teoretis dan konseptual yang membentuk atau mempengaruhi studi tentang permasalahan penelitian yang terkait dengan makna yang dikenakan oleh individu atau kelompok pada suatu permasalahan sosial atau manusia. Penelitian ini mengambil jenis kualitatif deskripsi mendalam (thick description).

Fokus penelitian ini yaitu pada bentuk kemiskinan warga desa yang ditinjau dari aspek morfologi sosial yang terkait dengan spasialitas, yaitu ruang fisik dan ruang sosial warga desa.

\section{HASIL DAN PEMBAHASAN}

Kemiskinan merupakan konsep yang tidak pernah habis untuk diperbincangkan. Bahkan program -program pengentasan kondisi tersebut juga tak pernah surut dibidani pemerintah hanya sering kali hasilnya masih jauh dari menggembirakan (Daraba, 2015). Maka memang dibutuhkan lintas disiplin pengetahuan untuk menterjemahkan apa itu yang dimaksudkan dengan kemiskinan. Masalah kemiskinan di perdesaan dalam penelitian ini diartikan sebagai bentuk kebudayaan terkait fenomena kehidupan masyarakat desa. Hal ini juga diperkuat oleh ungkapan Clifford Geertz mengenai budaya yang berisi jaringan kompleks yang berisi baik tanda dan simbol dalam bentuk rutinitas dan kebiasaan (Geertz dalam Sutrisno dan Putranto, 2005: 28). Rutinitas dan kebiasaan tersebut ada di dalam beragam bentuk konstruksi mental yang didasarkan pada pengalaman sosial, bersifat lokal dan spesifik, serta tergantung pada pihak yang melakukan (Salim, 2006:71).

Pengukuran kemiskinan yang berpijak pada perspektif "kemiskinan pendapatan" (income poverty) - yang menggunakan pendapatan sebagai satu-satunya indikator "garis kemiskinan" - juga merupakan bukti dari masih kuatnya dominasi model ekonomi neo-klasik di atas. Meskipun GNP dapat dijadikan ukuran untuk menelaah performa pembangunan suatu negara, banyak ahli menunjukkan beberapa kelemahan dari indikator ini.

Karena indikator GNP dan pendapatan memiliki kelemahan dalam memotret kondisi kemajuan dan kemiskinan suatu entitas sosial, sejak tahun 1970-an telah dikembangkan berbagai pendekatan alternatif. Di antaranya adalah kombinasi garis kemiskinan dan distribusi pendapatan yang dikembangkan Sen (1973); Social Accounting Matrix (SAM) oleh Pyatt dan Round (1977); Physical Quality of Life Index (PQLI) yang dikembangkan Morris (1977) (lihat Suharto, 2006). Pada tahun 1990-an, salah satu lembaga dunia, yakni UNDP, memperkenalkan pendekatan "pembangunan manusia" dalam mengukur kemajuan dan kemiskinan, seperti Human Development Index (HDI) dan Human Poverty Index (HPI). Pendekatan yang digunakan UNDP relatif lebih komprehensif dan mencakup faktor ekonomi, sosial, dan budaya si miskin.

Di sisi yang lain morfologi sosial juga sangat terkait dengan ide-ide tentang ruang atau spasial. Seperti Peter Haggett (1965) yang melihat bahwa ruang didefinisikan oleh hubungan antara entitas-entitas yang termuat di dalamnya. Teori ruang yang paling menarik dan berpengaruh yang menjadi landasan kerja penelitian ini adalah Lefebvre, Henri yang menghubungkan organisasi ruang dengan struktur kehidupan sehari-hari, yang dalam penelitian ini terkait dengan isu tentang kemiskinan di perdesaan. Diperkuat bahwa konsekuensi proses sosial dari produksi ruang fisik dan bukan konsekuensi langsung dari determinan ruang fisik tersebut ( Scott, 2012).

Menterjemahkan masyarakat desa pada masa ini, kita akan dihadapkan pada banyak sekali definisi sosiologis maupun politik-administratif yang satu dengan lainnya akan saling berkaitan. Namun untuk kepentingan 
penelitian ini, pemahaman akan masyarakat desa lebih merujuk pada aspek sosiologis meskipun tetap tidak mengabaikan pemahaman politis-administratifnya. Wawancara langsung tentunya menjadikan gambaran utuh. Hal ini merupakan langkah dalam menemukan pengertian dan pemahaman tentang suatu fenomena dalam suatu latar dan setting khusus. Setting tersebut terdiri dari akumulasi secara holistik pada perilaku, persepsi, tindakan dan berbagai elemen pendukung yang penting (Moleong, 2006: 5).

Dari hasil pemetaan sosial desa yang dilakukan di awal penelitian ini, diketahui bahwa jumlah mata pencaharian warga dapat digambarkan dalam tabel berikut ini.

Tabel 1. Mata Pencaharian Masyarakat Desa Sumber Salak

\begin{tabular}{clc}
\hline No. & \multicolumn{1}{c}{ Mata Pencaharian } & Prosentase \\
\hline 1. & Pertanian & 87 \\
2. & Pemerintahan/pelayanan publik & 1 \\
3. & Jasa Perdagangan & 3 \\
4. & Jasa Keterampilan/pertukangan & 5 \\
5. & Jasa Lainnya (ojek, sopir, tukang & 2 \\
6. & Secak) & 0 \\
7. & Sektor Industri lain (TKI, pembantu) & 2 \\
\hline & $\quad$ Jumlah & $\mathbf{1 0 0}$ \\
\hline
\end{tabular}

Sumber: Hasil Pemetaan Sosial dengan model FGD, 2015

Data tersebut di atas bukan merupakan data prosentase akurat dengan perhitungan statistik, namun dapat digunakan untuk mencerminkan bagaimana pandangan warga masyarakat setempat perihal kondisi sosial mereka terkait dengan pekerjaan warga yang ada di Desa Sumber Salak. Dari data itu pula terlihat bagaimana mereka sebagai warga masyarakat setempat mempersepsikan diri mereka sebagai kolektif besar dengan mata pencaharian utama di bidang pertanian. Terdapat 2 (dua) kategori untuk petani di desa ini, yaitu pertama kategori petani pemilik lahan yang jumlahnya sangat sedikit dan kedua, petani penggarap atau buruh tani dengan jumlahnya yang banyak. Petani sebagai pekerjaan mayoritas ini menyajikan gambaran kesenjangan yang mencolok sekali dari sisi ekonomi dan kehidupannya. Petani pemilik lahan merupakan sosok warga kaya yang dengan mudah dapat ditandai dengan bangunan rumah mereka yang besar yang bagus. Kondisi rumah kecil dan semi permanen, cenderung kumuh serta ditandai dengan terbatasnya atau sempitnya rumah dan lahan pekarangannya adalah petani miskin, alias warga yang pekerjaannya adalah sebagai buruh tani.

Desa Sumber Salak dengan posisinya di wilayah lereng gunung mempunyai kondisi lingkungan yang berkarakteristik hutan dan perbukitan dengan sedikit wilayah yang datar. Di atas landscape tanah-tanah hutan seperti itulah warga masyarakat dari awal kesejarahan mulai mengembangkan kehidupannya sedemikian rupa sehingga terjadilah bentukan ruang fisik yang dihidupi dan menghidupi warga masyarakatnya. Dihidupi dalam arti warga mulai menempati (tinggal dan bermukim) dengan memanfaatkan ketersediaan sumber daya alam hutan yang ada, sehingga kehidupan lingkungan hutan tersebutbertambah kompleks dengan kehadiran manusia. Menghidupi merupakan efek balik atas tindakan manusia atau warga yang menempati lingkungan hutan tersebut yang membawa manfaat besar untuk manusia atau warganya - artinya lingkungan dengan sumber daya alam hutan tersebut memberikan manfaat yang mampu menghidupi manusia yang menempatinya.

Secara nyata, lingkungan fisik di daerah ini yang dulunya belantara hutan mulai terbuka karena kepentingan untuk bisa membuat pemukiman dan bercocok tanam. Proses ruang dan lingkungan fisik yang dihidupi ini nampak dari adanya bentangan fisik alam atau landscape wilayah yang berangsur-angsur berubah dari hutan belantara menjadi lahan-lahan pertanian dan hunian warga.

Demikian berlangsung terus hingga jumlah warganya terus bertambah dan proses pemanfaatan lingkungan alam di wilayah ini bertambah intensif dengan kehadiran orang-orang yang mulai menempatinya. Dalam perjalanan waktu hingga di titik penetapan batas administrasi wilayah oleh pemerintah daerah, wilayah ini menjadi bagian dari Desa Pakuwesi yang disebut sebagai dusun Sumber Salak, menjadikan luasan wilayahnya terbatasi (tidak bisa meluas lagi) karena berbatasan dengan wilayah administratif yang lain dan wilayah perhutani yang merupakan wilayah milik negara. Dengan pembatasan wilayah tersebut dan beriringan dengan jumlah warga yang terus bertambah maka terjadilah intensifikasi lahan oleh warga masyarakat Sumber Salak.

Namun intensifikasi lahan yang dilakukan oleh warga tidak mengalami progresivitas yang tinggi, karena belajar dari pengalaman pertanian selama waktu berjalan bahwa di wilayah ini dengan mempertimbangkan iklimnya hanya ideal untuk jenis tanaman tertentu, seperti padi, jagung, tembakau, bawang, dan cabe. Tetapi apapun itu, pada dasarnya sejak keberadaan mereka di wilayah Sumber Salak ini yang secara khusus memanfaatkan lingkungan fisik dengan praktik atau intensifikasi pertaniannya telah terjadi produksi ruang di lingkungan Sumber Salak oleh warga masyarakatnya.

Produksi ruang ini terjadi dengan membawa konsekuensi yang jauh terhadap praktik keruangan mereka sedemikian rupa dengan manifestasi atas tindakan keruangan itu menjadikannya warga desa terbaca sebagai masyarakat pertanian. Secara lebih nyata akan dijelaskan lebih lanjut terhadap produksi ruang ini pada pokok-pokok sub-bahasan berikutnya.

\section{Pertanian dan Tantangan Iklim}

Pertanian dengan segala bentuk praktiknya merupakan upaya warga Desa Sumber Salak dalam 
memproduksi ruang lingkungan tinggal mereka. Peruangan yang terpenting bagi keberadaan mereka adalah bagaimana landscape wilayah Sumber Salak dimanfaatkan sedemikian rupa untuk pertanian bagi pemenuhan kebutuhan ekonominya melalui penanaman bibit-bibit tanaman produktif dengan cara pengolahan petak-petak lahan. Produksi ruang lewat pertanian demikian itu nampak dari tindakan-tindakan warga yang dulunya diawali dengan membuka wilayah-wilayah hutan atau biasa disebut dengan istilah ekstensifikasi lahan, yaitu usaha meningkatkan pertanian dengan cara memperluas lahan pertanian baru. Usaha ekstensifikasi mereka pada tahap dini sewaktu di awal-awal membuka wilayah ini dilakukan dengan teknik menebang dan membakar (slash and burn). Teknik klasik ini dimulai oleh para pendahulu mereka, seperti yang disampaikan oleh salah seorang warga desa yang juga dikuatkan oleh pernyataan dari sesepuh desa.

Awal dari pembukaan lahan produksi ruang yang dilakukan oleh warga ini pada akhirnya menjadikan polapola dan tindakan hidup mereka tidak bisa dijauhkan dari aspek pertanian. Hal ini sebagai sebuah akibat bahwa produksiruangyang dilakukanternyatatelahmembuahkan hasil dari sisi pemenuhan kebutuhan hidup mereka. Demikian selanjutnya produksi ruang terus berjalan dari ekstensifikasi lahan dengan teknik-teknik tradisional yang sekarang sudah tidak mungkin lagi dilakukan, mengarah pada intensifikasi lahan terhadap lahan-lahan yang ada hingga kini. Bagaimanapun juga intensifikasi ini adalah upaya mereka untuk meningkatkan hasil pertanian dengan cara mengoptimalkan lahan pertanian yang sudah ada, karena pembukaan lahan sudah tidak dimungkinkan semenjak penetapan batas administrasi desa diberlakukan oleh pemerintah daerah Bondowoso. Dalam melakukan intensifikasi pertanian, mereka menggunakan cara-cara yang umumnya dilakukan oleh petani yakni berusaha mengolah tanah sesuai dengan kepentingan tanamnya, membuat irigasi untuk menghadirkan kebutuhan air bagi tanaman, mereka juga memilih bibit-bibit yang akan ditanam, juga mereka melakukan pemupukan dan apabila terdapat hama mereka akan segera memberantasnya. Apa yang mereka lakukan ini dalam istilah pertaniannya sering disebut dengan panca usaha tani.

Hal penting yang dilakukan oleh warga Desa Sumber Salak dalam produksi ruang pertaniannya adalah dengan memperhatikan iklim. Faktor ini menjadi sangat penting bagi usaha pertanian. Seperti halnya di wilayah
Indonesia secara umum akan terbagi menjadi dua musim, yaitu musim hujan dan musim kemarau. Kedua musim ini dengan iklimnya masing-masing menjadikan penentuan jenis tanaman yang akan ditanam sebagai strategi pertanian mereka. Di samping faktor iklim, dalam melakukan aktivitas produksi ruang pertaniannya mereka juga membaca faktor komoditas yang sedang meningkat permintaannya. Kedua faktor umum tersebut menjadikan upaya pengolahan lahan dan produksi ruang mereka terkesan sangat khas sekali dari tahun ke tahun karena kebergantungan mereka atas kedua faktor yaitu iklim dan komoditas. Dari keterangan ini sebelumnya akan digambarkan dulu pola musim tanam mereka melalui gambar skema pertanian 1 sebagai berikut.

Dari pola musim tanam mereka terlihat bagaimana produksi ruang pertanian mereka sangat bergantung dengan adanya iklim atau musim. Musim kemarau yang biasanya jatuh mulai dari bulan April hingga Oktober akan banyak dimanfaatkan oleh warga desa dengan menanam tanaman palawija seperti tembakau, jagung, bawang, dan cabe. Di musim hujan yang jatuh di bulan November hingga bulan Maret akan banyak dimanfaatkan lahan mereka untuk tanaman padi. Pada musim kemarau khususnya akan terlihat bagaimana diversifikasi tanam lebih terlihat dari pada di musim hujan (Rencana Pembangunan Jangka Menengah Daerah (RPJMD) Kabupaten Bondowoso Tahun 2009-2013: 3).

Nampak sekali bahwa apa yang dilakukan warga petani di Desa Sumber Salak ini terlihat bahwa mereka adalah petani sebagai pengolah tanah di perdesaan, yang mana pertimbangan atau pilihan rasional menjadi keberlakuan warga di desa ini (Sajogyo, 2006: 294).

Adaptasi yang terpenting adalah masalah adaptasi terhadap iklim atau musim. Di atas telah diterangkan bahwa mereka hidup dengan dua iklim atau musim, yaitu musim kemarau dan musim hujan. Morfologi kedua musim ini menciptakan pola-pola sosial tertentu yang berbeda namun tetap berkaitan satu terhadap yang lain. Musim hujan dianggap sebagai musim yang paling dirasakan berat karena dalam pertanian tidak banyak menghasilkan pendapatan uang tunai, karena hasil pertanian padi di musim hujan tidak dijual ke pasar melainkan dikonsumsi sendiri. Hal ini merupakan bentuk adaptasi mereka terhadap datangnya iklim atau musim kemarau di bulan-bulan mendatang yang nampaknya akan sangat terbantu dengan ketersediaan/ stock padi atau beras di rumah-rumah mereka.

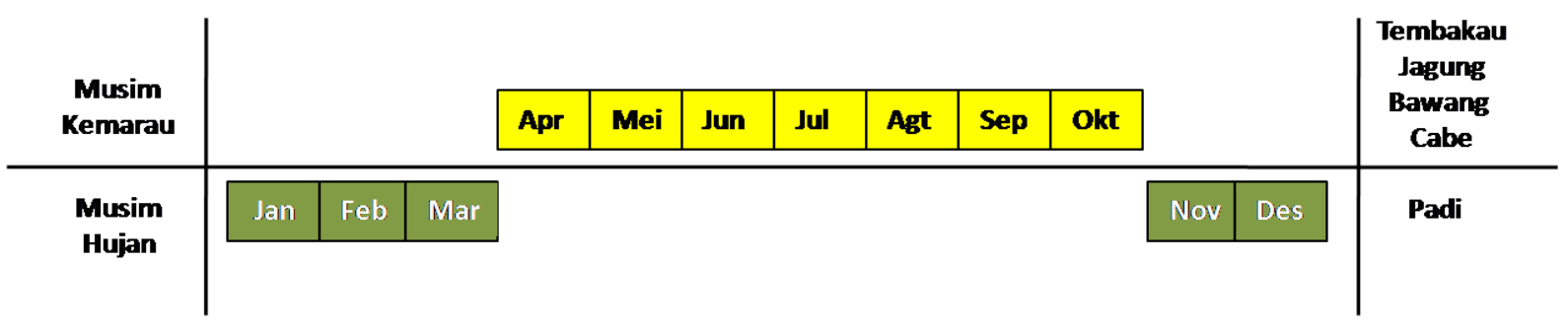

Gambar 1. Pola Musim Tanam Desa Sumber Salak 
Walaupun banyaknya padi yang diperoleh dari keseluruah warga berbeda-beda satu terhadap lainnya, tetapi perbedaan yang berlaku umum adalah $30 \%$ hasil pertanian padi untuk buruh taninya dan 70 $\%$ hasil panen padi diperuntukkan bagi pemilik lahan atau sawah. Rata-rata pemilik lahan atau pemilik tanah akan melakukan adaptasi tahunan yang cukup sukses menghadapi musim kemarau dan sekaligus masuk di musim penghujan tahun depannya. Berbeda dengan para warga yang bekerja sebagai buruh taninya. Hasil $30 \%$ dari panen padi rata-rata tetap tidak mencukupi kebutuhannya - jangankan mencapai musim kemarau atau musim penghujan di tahun-tahun mendatang. Untuk sampai selama 2-3 bulan ke depan saja hasil panen padinya tidak mencukupi untuk kebutuhan hingga musim berganti tahun depannya. Apa yang harus dilakukan oleh warga buruh tani ini adalah adaptasi yang lebih sulit untuk bisa terhindar dari pergantian musim ke musim kemarau, meskipun hanya untuk 2-3 bulan.

\section{Ruang Sosial: Lingkungan dan Pertanian sebagai Pembentuk Struktur Sosial Masyarakat}

Sebelumnya apa yang disebut dengan produksi ruang pertanian sebagaimana halnya yang telah diuraikan di atas pada akhirnya akan sangat berpengaruh pada pembentukan ruang sosial mereka yang lebih abstrak tetapi sangat jelas berlaku dalam tatanan hidup mereka. Hal ini terbangun akibat dari produksi ruang dengan ciri-ciri pertanian mereka sebagaimana lingkungan yang mereka olah. Untuk lebih jelasnya akan diuraikan bagaimana produksi ruang dengan lingkungan yang diolah tersebut menjadikan ciri-ciri pertanian mereka dan membentuk ruang sosial yang lazimnya kita sebut dengan istilah struktur sosial.

Pertama, wilayah yang dulunya hutan belantara di lereng-lereng gunung oleh para warga pendahulu dibuka dengan maksud untuk membuat lahan-lahan tersebut menjadi produktif sebagai lahan pertanian.

Kedua, perbedaan antara warga yang mampu yang memiliki lahan dengan warga yang kurang mampu yang tidak memiliki lahan memiliki pola hubungan tertentu di antara keduanya dalam konteks pengolahan lahan atau pertanian.

Maka terlihat bagaimana pola atau struktur sosial dari kehidupan keseharian warga di Desa Sumber Salak ini. Struktur sosial demikian itulah yang terbangun di desa ini, karena keterikatan satu elemen dengan elemen lainnya dalam segi-segi kehidupan keseharian mereka.

\section{Morfologi Sosial dan Sebab Kemiskinan Warga Sumber Salak}

Berbicara struktur sosial di Desa Sumber Salak tidak bisa dilepaskan dari pembacaan morfologi sosial di desa ini, yang berarti bahwa determinasi faktor lingkungan fisik baik alam maupun iklim [sebagai domain] yang berpadu dengan kehidupan ekonomi sosial [sebagai akibat] yang berlangsung dalam kehidupan warga masyarakat Desa Sumber Salak merupakan bentuk produksi ruang yang dengan konsekuensinya menjadikannya sebagai sebuah bentuk struktur sosial. Struktur sosial yang dimaksud ini merupakan jalinan yang menghadirkan kesulitan tersendiri bagi mayoritas warga untuk bisa keluar dari kondisi yang disebut dengan kemiskinan.

Morfologi sosial didasarkan atas keadaan atau kondisi lingkungan dengan sekaligus sifat kepemilikan lahan, kondisi iklim/musim, penentuan tanaman pertanian berdasar musim dan potensi pasar (komoditas) hingga proses kerja warga di bidang pertanian adalah bentuk kehidupan ekonomi sosial masyarakat desa. Kesemuanya itu merupakan bentuk dari produksi ruang yang pada gilirannya menghadirkan karakteristik umum bagi mayoritas warga di Desa Sumber Salak ini. Demikian selanjutnya dengan segala kesulitannya mereka akan menghadapi musim hujan dan musim kemarau kembali secara bergantian. Untuk itu mereka akan selalu merasakan kesulitan-kesulitan yang nyaris tidak pernah ada putusnya dari waktu ke waktu.

Dengan morfologi sosial demikian itu pulalah akan menghadirkan efek kehidupan sosial yang terstruktur sedemikian rupa menjadi tatanan sosial bagi kehidupan warga masyarakat di Desa Sumber Salak. Permasalahan muncul manakala struktur sosial ini begitu kuatnya yang secara kolektif mempengaruhi prilaku-perilaku warga masyarakat, prilaku penting yang sangat menonjol adalah perilaku ekonomi warga lewat domain pertaniannya yang bagi sebagian besar warga/ mayoritas dirasakan menyulitkan dan tidak mencukupi untuk pemenuhan kebutuhan hidupnya - yang dengan kata lain sebagai bentuk kemiskinan.

Dari situ kita dapat membaca bahwa kemiskinan yang terjadi di Desa Sumber Salak yang hingga sekarang ini masih terus mendera mayoritas warga desa diawali dari lahan dan sifat kepemilikan lahan, produksi ruang hidup mereka lewat pertanian hingga menjadi struktur sosial yang menopangnya dan pada akhirnya berdampak pada "kelanggengan" kondisi kemiskinan mayoritas warga di desa ini. Maka robohnya ketahanan pangan nasional tinggal menuju waktu, jika petani masih termarjinalkan (Aminah, 2015)

\section{SIMPULAN}

Apa yang dapat disimpulkan dari penjelasan tentang kehidupan warga masyarakat di Desa Sumber Salak adalah bahwa pada masyarakat desa ini ternyata merupakan potret dari wajah kemiskinan di wilayah yang memiliki karakter khusus, yaitu berkenaan dengan produksi ruang di lingkungan fisik/alam dan di lingkungan sosial yang merupakan bentuk dari morfologi sosial yang memberikan efek terhadap pembentukan struktur sosial kehidupan warga desa. Dari masing-masingnya terlihat 
sekali bahwa efek dari produksi ruang sebagai bentuk morfologi sosial tersebut memang menggambarkan kondisi kemiskinan di desa ini.

Hal tersebut didukung dengan hasil yang ditemukan dari penelitian ini yang secara ringkas menunjukkan bahwa kondisi kemiskinan di desa ini disebabkan karena beberapa hal mendasar, yaitu: (1) mayoritas warga sebagai petani memiliki derajat ketergantungan yang tinggi terhadap tanah yang menjadi sumber penghidupan mereka di bidang pertanian, (2) dalam hal produksi ruang pertanian yang sangat bergantung pada iklim/ musim, yakni musim penghujan dan musim kemarau dengan jenis tanaman yang berbeda di antara kedua musimnya, (3) tingkat hasil produksi pertanian baik dari kedua musim tidak cukup memberikan keuntungan bagi pemenuhan kebutuhan hidup mayoritas warga miskin sebagai buruh petani karena ketiadaan kepemilikan lahan pertanian, lahan secara terbatas hanya dimiliki oleh segelintir warga kaya, dan (4) ketergantungan mayoritas warga miskin sebagai buruh tani terhadap warga kaya sebagai pemilik lahan erat kaitannya dengan produksi ruang (baik ruang di lingkungan fisik/alam maupun ruang di lingkungan sosial), yang dapat dibaca sebagai bentuk morfologi sosial mereka yang pada akhirnya tercipta struktur sosial yang disebut dengan kemiskinan.

\section{DAFTAR PUSTAKA}

Aminah, S dan Sumardjo. (2015). Strategi Peningkatan Keberdayaan Petani Kecil Menuju Ketahanan Pangan, Sosiohumaniora, 18 (3), 255-263.
Daraba, D. (2015). Faktor-Faktor Yang Mempengaruhi Keberhasilan Program PemberdayaanMasyarakat Miskin di Kecamatan Polongbangkeng Utara Kabupaten Takalar Provinsi Sulawesi Selatan, Sosiohumaniora, 17 (2), 165-169.

Lefebvre, H. (1991). The Production of Space. Translated by Donald Nicholson-Smith. Oxford: Blackwell.

Hugget, P. (1965). Location Analysis in Human Geography, London: Edward Arnold.

Moleong, L.J. (2006). Metodologi Penelitian Kualitatif. Bandung: Rosdakarya

Rencana Pembangunan Jangka Menengah Daerah (RPJMD) Kabupaten Bondowoso Tahun 2009-2013

Sajogyo. (2006). Ekososiologi: Deideologisasi Teori, Restrukturisasi Aksi (Petani dan Perdesaan Sebagai Kasus Uji). Yogyakarta: Cindelaras Pustaka Rakyat Cerdas.

Salim, A. (2006). Teori dan Paradigma Penelitian Sosial. Yogyakarta: Tiara Wacana.

Scott, J. (2012). Social Theory: Central Issues in Sociology. Yogyakarta: Pustaka Pelajar.

Suharto, E. (2006). Membangun Masyarakat Memberdayakan Rakyat. Bandung: Refika Aditama (cetakan kedua)

Sutrisno, M. dan Putranto, H. (2005). Teori-Teori Kebudayaan. Yogyakarta: Kanisius. 